Article

\title{
Determinants of the quality of the living environment, including PM 2.5 and PM10 dust pollution in the context of spatial issues - the Radzionkow case.
}

\author{
Rafał Blazy ${ }^{1, *(1)}$ \\ 1 Faculty of Architecture, Cracow University of Technology ; rblazy@pk.edu.pl \\ * Correspondence: rblazy@pk.edu.pl
}

\begin{abstract}
The article discusses determinants of living environment in Central and Eastern Europe. As an example, the city of Radzionkow was chosen, with 16 thousand inhabitants, located in the Silesia agglomeration in southern Poland, in the area where hard coal has been mined for almost two hundred years, which largely serves as a source of heating for houses and flats. 360 buildings in 6 groups of 60 buildings were examined in the selected city, which allowed to distinguish 3 different areas in terms of the quality of the living environment depending on the technical condition of buildings, the method of heating and location. To a large extent, determinants are the existing spatial and geophysical conditions of a given location. Many research and reports on the living environment do not take into account the factors mentioned, focusing only on the statistical data of pollution, excluding spatial factors. In the research presented, the author, taking into account location variables, shows differences in the measurements of air pollution in relation to the designated location zones depending on the morphological structure of the building, the degree of its modernization and the types of heating used in buildings.
\end{abstract}

Keywords: quality of the living environment, spatial location conditions, air pollution research, the problem of city ventilation, spending of EU funds to improve the quality of the environment

\section{Introduction}

In Central and Eastern Europe today, the problem of air pollution caused by inefficient heat sources has become one of the most important urban problems. On a macro scale, air pollution resulting from the use of fossil fuel as a heat source is extremely harmful to the Earth's climate due to the production of greenhouse gases, while taking into account the micro scale it directly has a negative impact on human health at local and regional scale (e.g. air pollution with PM2.5 and PM10) , [1],[2],[3]. These dust particles, due to their dimensions, are even transported over considerable distances by even weak winds. It was found that solid particles $(0.1-1 \mu \mathrm{m})$ can be moved even up to a distance of several thousand kilometers [4]. The latest research [5] shows that a significant amount of PM 10 excreted in Silesia is able to cover several hundred kilometers to eastern or northern Poland, and even to Scandinavia. Air pollution in this region of Poland is one of the external factors of air pollution, among others in eastern Czechoslovakia [6]. Poland, with Bulgaria, is one of the countries with the highest level of PM10 air pollution (above $50 \mu \mathrm{g} / m 3$ ) in Europe [7],[8][9]. Both high-altitude and low-altitude emissions have a significant impact on measurable and perceptible air quality in a given area [10],[11],[12],[13],[14],[15]. Emissions at 40 meters above ground level are considered to be high altitude emissions. Emissions at "low altitudes" include all sources of dust pollution up to a height of $40 \mathrm{~m}$. In Poland, pollution at low altitudes is mainly caused by individual home furnaces and local boiler, and to a lesser extent with transport.

Pollution with fine particles (PM 2.5 and PM10) is one of the most important research problems nowadays [16]. PM 2.5 particles, consisting of particles smaller than $2.5 \mathrm{~m}$ in diameter and PM 10 
particles between $2.5 \mu \mathrm{m}$ and $10 \mu \mathrm{m}$ in diameter, are extremely dangerous. Man breathing fluctuations very dangerous substances that get into the human body cause various diseases of the respiratory and cardiovascular systems [17]. Epidemiological studies confirm that permanent exposure to PM 2.5 significantly contributes to a higher incidence of cardiopulmonary disease, and complications that even lead to increased mortality among the population [18], [19]. Therefore, a better and more comprehensive understanding of all conditions related to PM 2.5 and PM 10 pollution is necessary. This can be of great importance in preventing pollution and protecting human health. Much research has been conducted around the world on PM 2.5 and PM10 dust pollution, mainly focusing on spatial issues and the time of occurrence of pollution [5-10], sources of pollution [20], [21],[22],[23], and health effects on humans [24],[25][26][27]. Also, studies on the estimates [28][29][30][31].

Studies have shown that on a macro scale meteorological conditions have an impact on the direct impact of PM 2.5 and PM 10 pollutants [32],[33][34][35]; on a micro scale, PM 2.5 pollution is strongly associated with land use [36][37][38][39]. Some researchers suggest that there is scope for optimizing land use and use to reduce PM 2.5 and PM 10 pollution at city level [40],[41],[42]. However, there is a noticeable lack of research characterizing the strong link between spatial development and the compositional system and terrain topography in the context of the occurrence of particulate pollutants PM 2.5 and PM10 k [37], [43]. Therefore, an attempt to determine the impact of land use on PM 2.5 and PM10 pollution showing the distribution of pollutants in different functional and spatial zones seems necessary and significant even in the individual case with very characteristic climatic, terrain and spatial conditions, which is Radzionkow in southern Poland.

There is not enough data available to carry out research on the impact of land use on the degree of PM 2.5 and PM10 dust pollution, which is a major research challenge. Several attempts have been made during the current decade. Interpolation of pollutant concentrations is based on dense monitoring grids, while in reality monitoring sites are usually rare and include at most several locations in large cities or single points in small cities. Dispersion models simulating the fate of pollutants may be useful in some cases, but their dependence on many spatial variables requires very accurate output data [44],[45].

In Poland, in recent years, energy and climate policy in the field of counteracting air pollution is increasingly present in public debates, political decisions and scientific research. However, it is more often associated with problems of the mining and energy sector than the problems of direct pollution of urban areas. The common opinion among Polish citizens is that the air in small-town and rural areas is clean and more healthy than in large cities and metropolises. However, scientific publications in this field prove that the situation is quite the opposite - air in small towns and villages is often much more polluted than in cities [46],[47][48][49]. The problem of air pollution in small urbanized areas in Poland is largely due to the use of conventional old inefficient energy carriers and building heating systems [50]. The effects of burning low calorie coal include the emission of harmful components into the atmosphere such as sulfur dioxide ( $\mathrm{SO} 2$ ), nitrogen dioxide and nitrogen oxides (NO x), carbon oxides $(\mathrm{CO} x)$ and harmful solid particles. Among the solid particles, the most dangerous to health and life are fine particles with a diameter below $10 \mu \mathrm{m}$, including PM2.5 and PM10 dust [51]. Direct inhalation of particulates (PM2.5) is associated with an increased incidence of cardiovascular disease [52]. The components of these particles often also include other impurities such as arsenic, cadmium, nickel and some polycyclic aromatic hydrocarbons such as benzo (a) pyrene, which are considered mutagenic, as well as substances that contribute to carcinogenicity, they are also one of the most dangerous ingredients that pollute the atmosphere [53],[54].

The burning of conventional energy carriers such as hard coal contributes to the degradation of the natural environment: in the form of the greenhouse effect, water and soil pollution, etc. In small-town and rural areas in Poland there is also a problem associated with the modernization of old electrical networks. There are also no gas installations and networks.

The quality of the living environment depends on many factors] [55]. To a large extent, determinants are the existing spatial conditions of the location. When considering air quality, the 
pollution occurring, the topographic layout of a given locality and the spatial structure of buildings are important. Many reports on the living environment do not take into account these factors by focusing solely on the statistics of pollution, excluding spatial factors [56],[57],[58]. In the presented studies, the author, taking into account location variables, shows differences in the measurements of air pollution in relation to the designated location zones depending on the morphological structure of the building.

\section{Subject and method of research}

Radzionkow is a city and a commune in southwestern Poland, in the Slaskie Voivodeship, in the Tarnogorski county, in the northern part of the Upper Silesian Industrial District (GOP), which is one of the most important cultural, scientific and economic centres in Poland. The oldest mentions about Radzionkow come from 1326-1357 year. The subject of the study was the northern and central part of the Radzionkow commune. In terms of morphology, the central part of the building is a preserved oval system with a historic route. Most of the buildings are located along streets marked out along the plot boundaries. Buildings in the frontage of the ovary have a regional frontage, stone, classicizing character - characteristic for the end of the 19th and the beginning of the 20th century. Historicizing architecture is complemented by modernist and functionalist buildings. Most residential buildings were built after the Second World War in a modernist and postmodern style. In the eastern part of the village, there is a railway line separating part of the village (communication connection via historic viaducts under the railway lines). In the eastern part of the village, there is the Silesian Insurgents Mountain Park and the Silesian Botanical Garden.

The types and types of city heating zones were determined by the preliminary acceptance of 6 characteristic areas in which they were selected due to their location, similar building structure in terms of age and type of buildings, and similar topography. In these areas, 60 buildings were randomly selected and analyzed and their heating and insulation method was checked. In total, 360 buildings in 6 groups of 60 buildings were tested in the city. The obtained results allowed defining and determining 3 basic urban zones characteristic in terms of heating and insulation of buildings (Figure 8).

As cross-section and explanatory material, 4 cross-sections of the terrain profile are presented, showing the valley character of the arrangement of buildings (Figure 1,2,3,4). In addition, one longitudinal section of the terrain was presented showing the rise of the land opposite to the direction of the inflow of fresh air along with the prevailing wind directions, i.e. from the south-west (Figure $5,6,7)$. Against the background of the existing building tissue, the dominant wind directions are presented, along with the marking of streets adapted to the ventilation directions of the city and streets constituting barriers and obstacles to ventilation (Figure 6,7). Initial research areas were designated, and after the analysis 3 dominant zones A, B and C were determined (Figure 8). Detailed tests and observations regarding PM2.5 and PM10 dust were performed for zone A (Figure 10). The performed tests were verified and compared with the Official documents [56], [57]. 


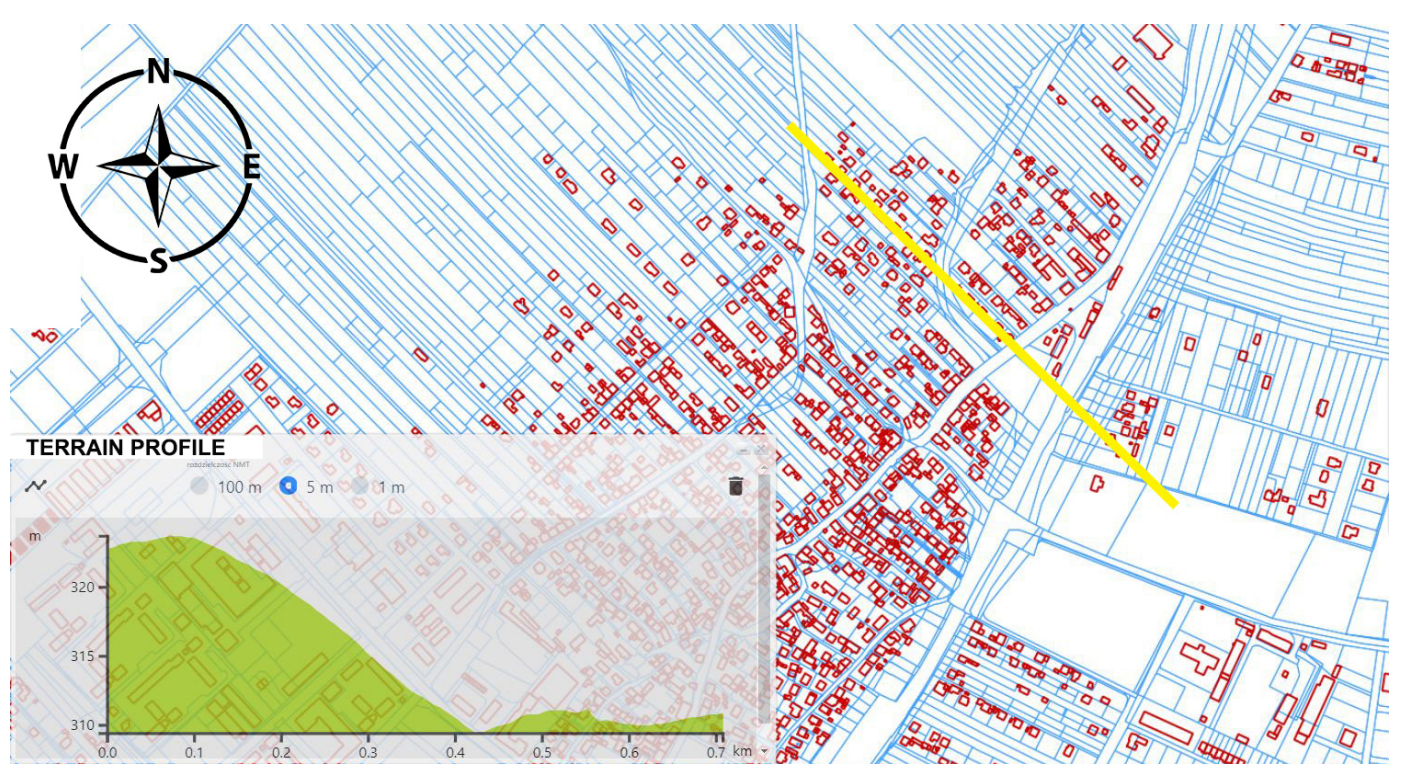

Figure 1. Cross-section through the beginning of the Radzionkow urban zone - the difference between the central and valley part is about $32 \mathrm{~m}$ and the terrain slopes from north-west to the centre of the valley is $7 \%$. (Author's drawing using data from https://mapy.geoportal.gov.pl).

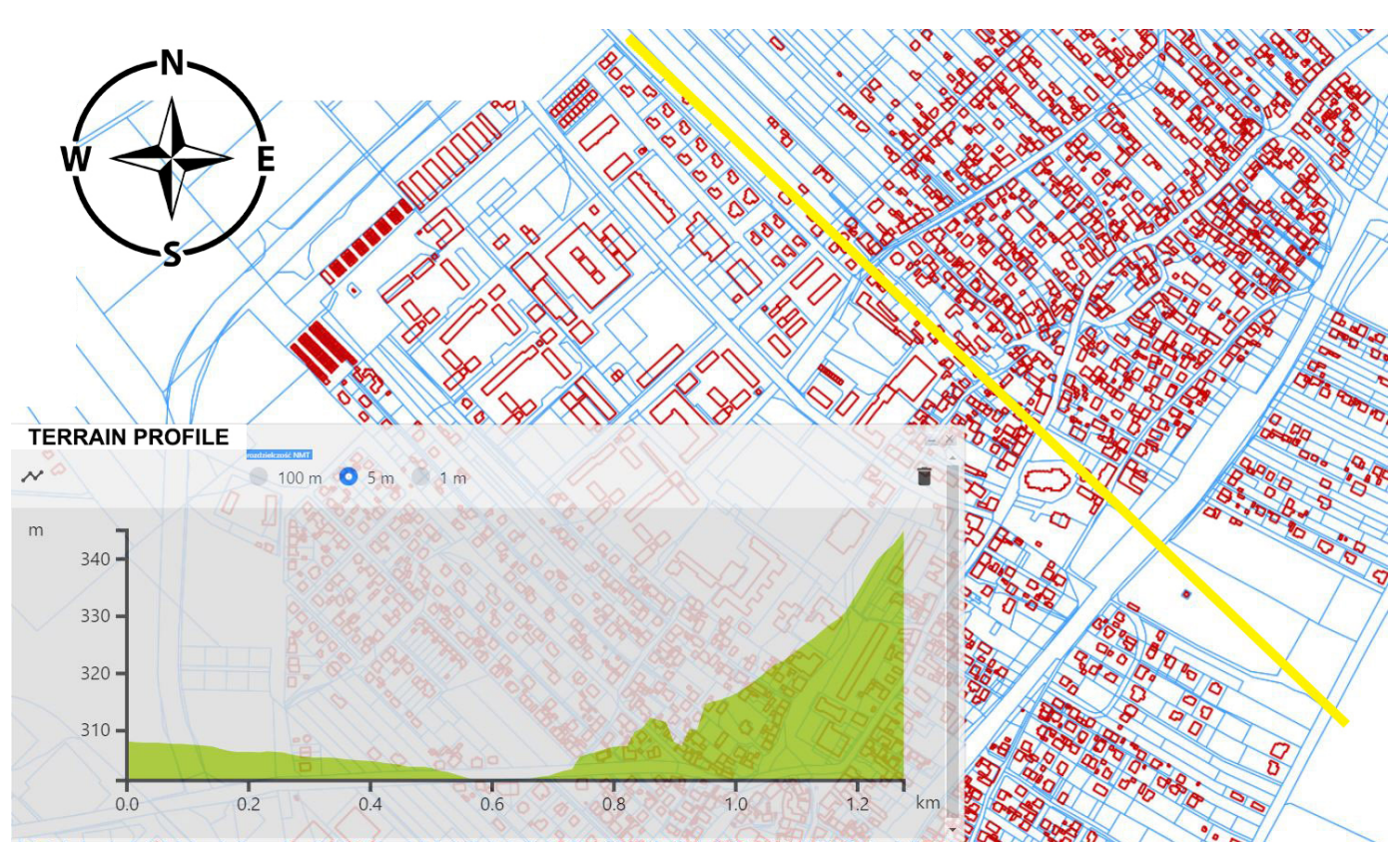

Figure 2. Cross-section through the central part of the Radzionkow urbanized area - the difference in levels between the valley part and the elevation from the south-eastern side is $45 \mathrm{~m}$, and the percentage decrease is 7\% . (Author's drawing using data from https://mapy.geoportal.gov.pl). 


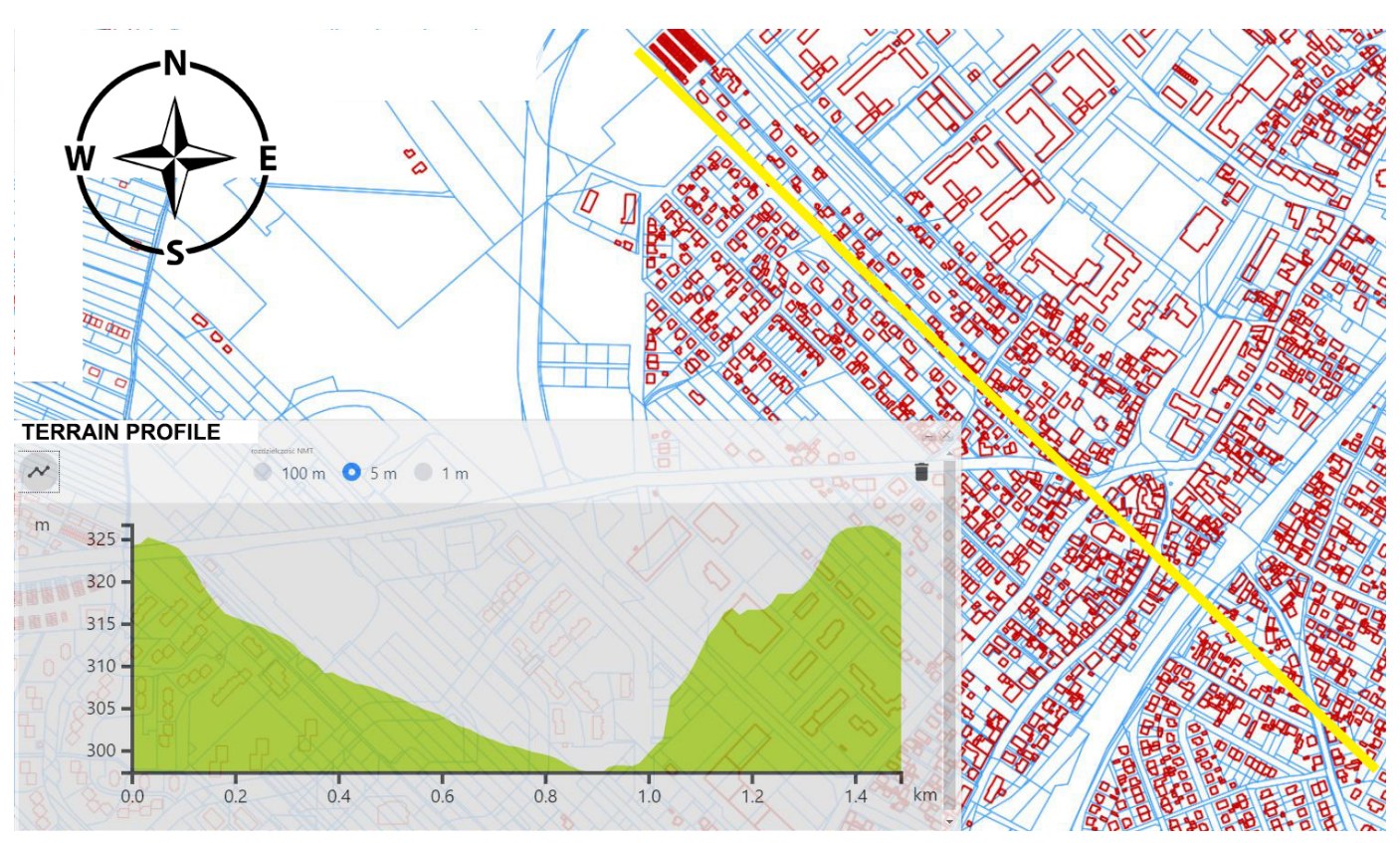

Figure 3. Cross-section through the valley the difference in levels is $30 \mathrm{~m}$ on the north-west side and 35 on the south-west side the width of the valley in this place is about $1400 \mathrm{~m}$. A decrease of $3.3 \%$ in the north and 5\% in the south. (Author's drawing using data from https://mapy.geoportal.gov.pl).

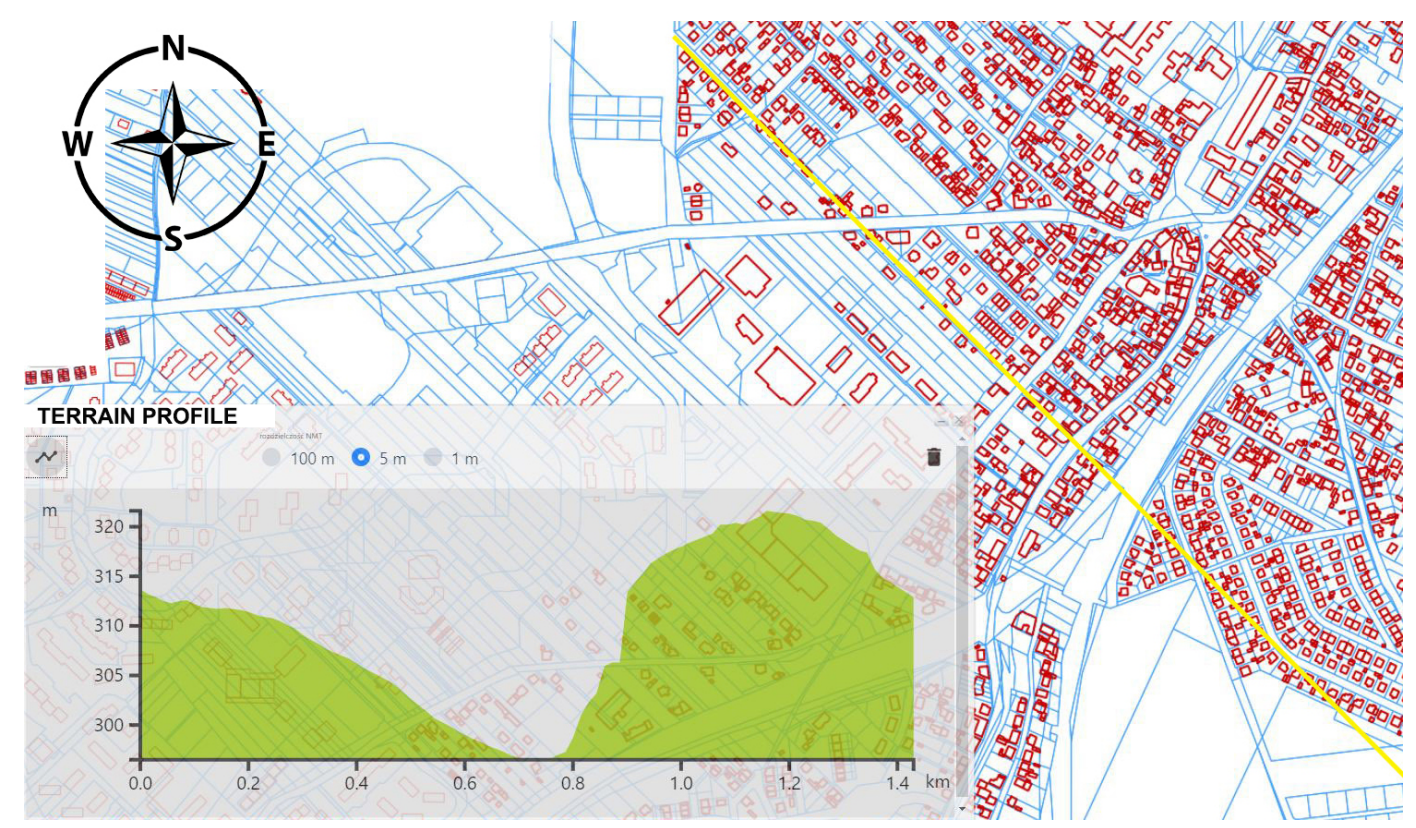

Figure 4. Cross-section of the urbanized area Radzionkow, the difference between the bottom of the valley and the surrounding hills is at the highest point $35 \mathrm{~m}$, in the cross-section, these are points less than $500 \mathrm{~m}$ apart, in this place the percentage of landfall is $7 \%$. (Author's drawing using data from https:/ /mapy.geoportal.gov.pl). 


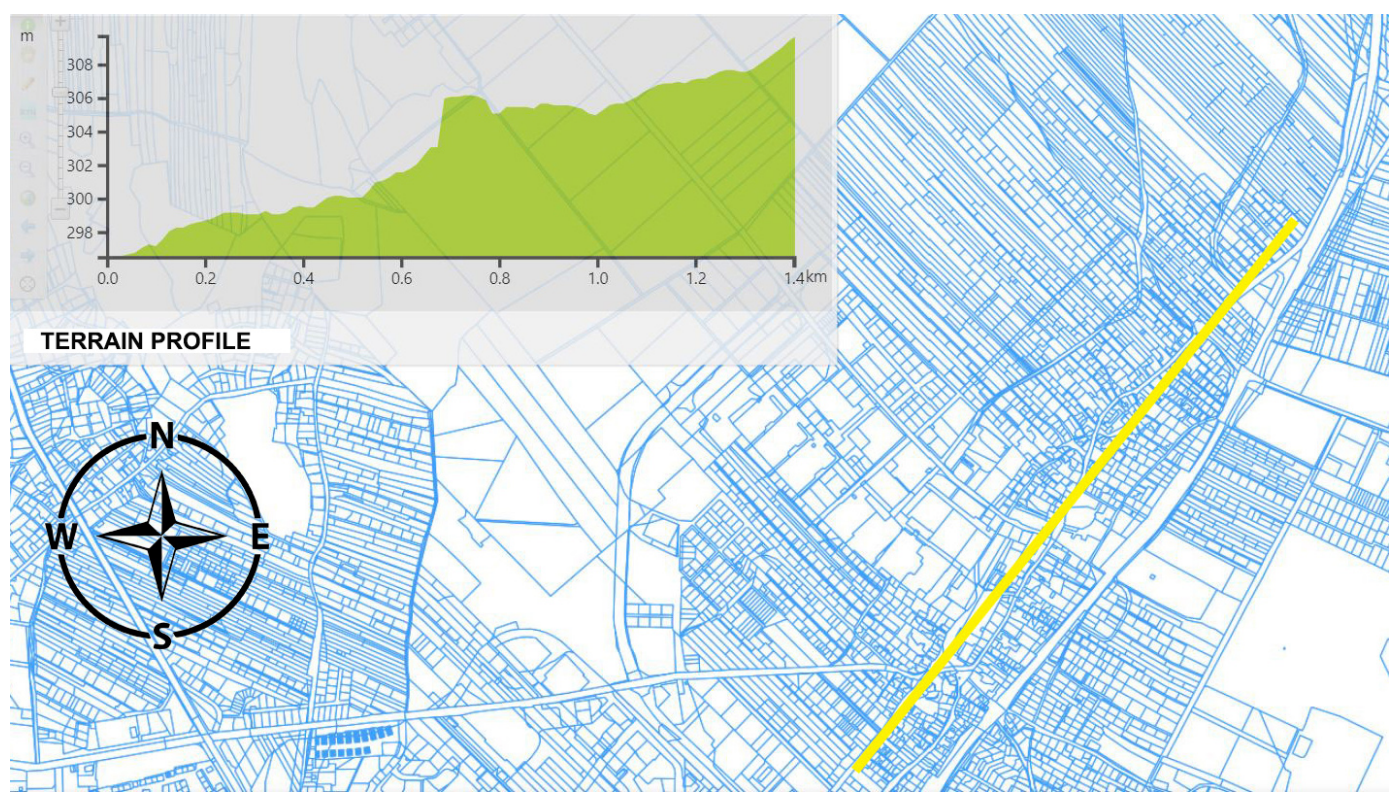

Figure 5. The longitudinal section within the urban area of Radzionkow - the difference in levels is 14 meters over a length of $1400 \mathrm{~m}$. (Author's drawing using data from https:/ / mapy.geoportal.gov.pl).

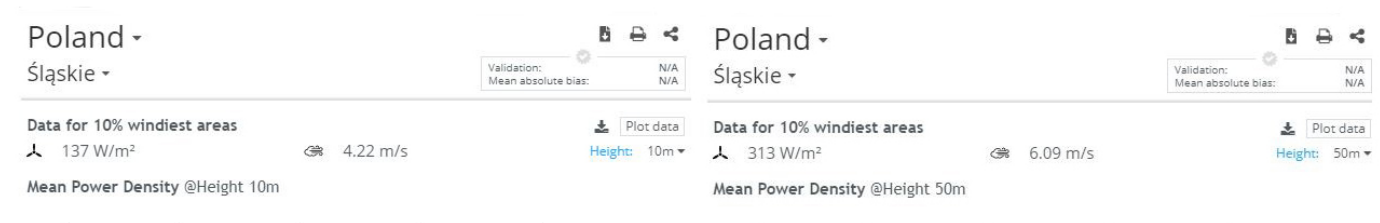
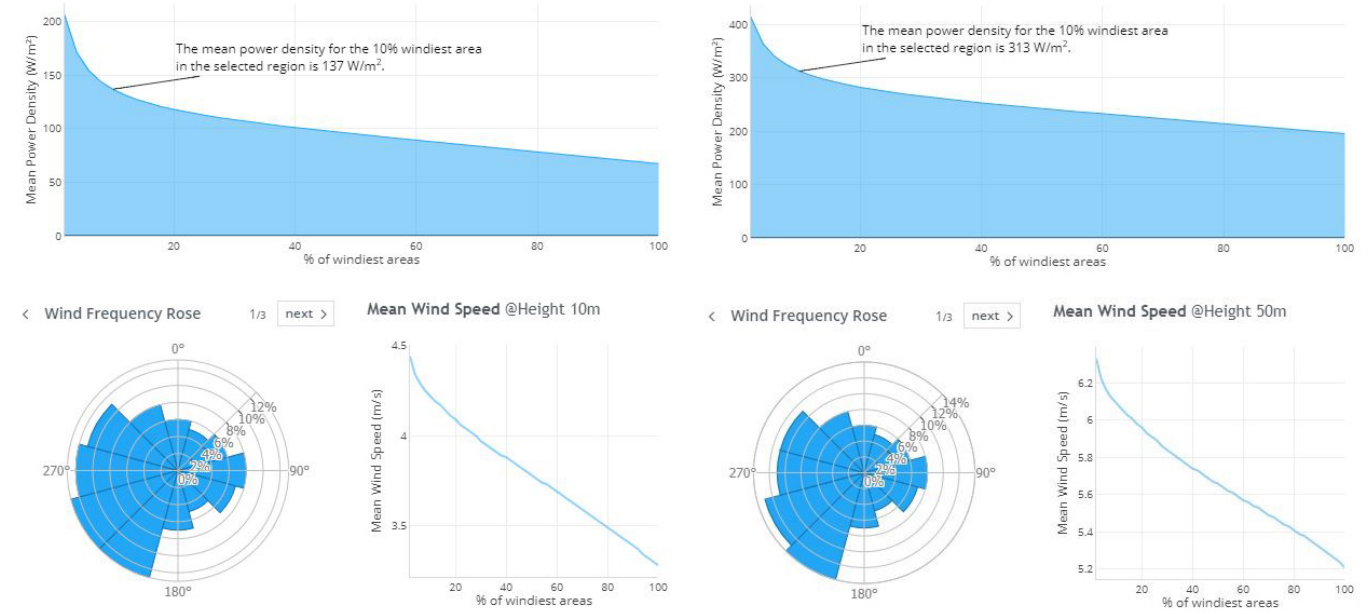

Figure 6. Directions of dominant winds for the Slaskie Voivodeship. (source: https://globalwindatlas.info/area/Poland/\%C5\%9Al\%C4\%85skie). 


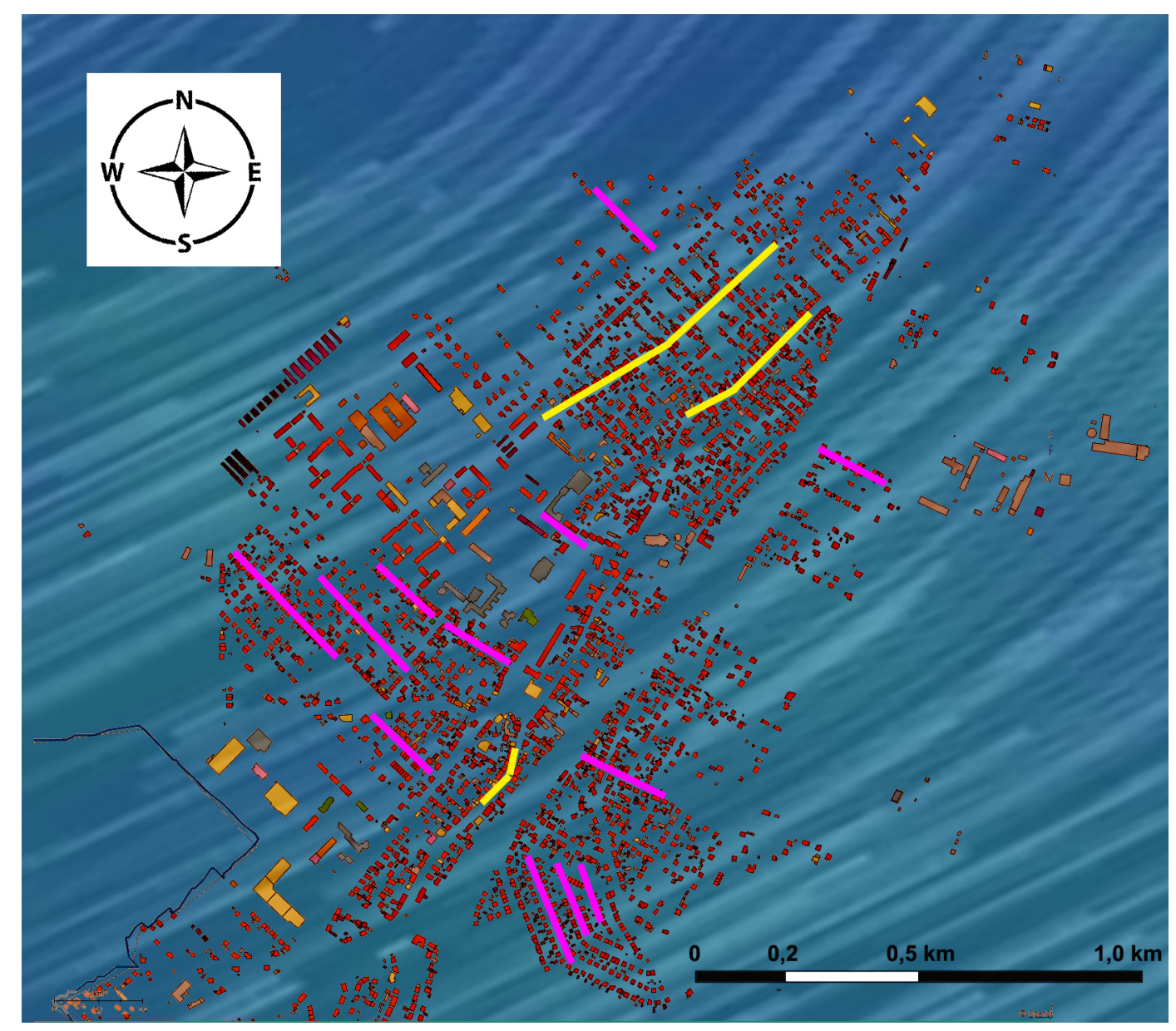

Figure 7. Radzionkow's building layout against the background of the dominant wind direction with directions of perpendicular roads shown (magenta colour) constituting barriers for the ventilation of the city, and few roads in accordance with the directions of the dominant number of winds (marked in yellow colour). 


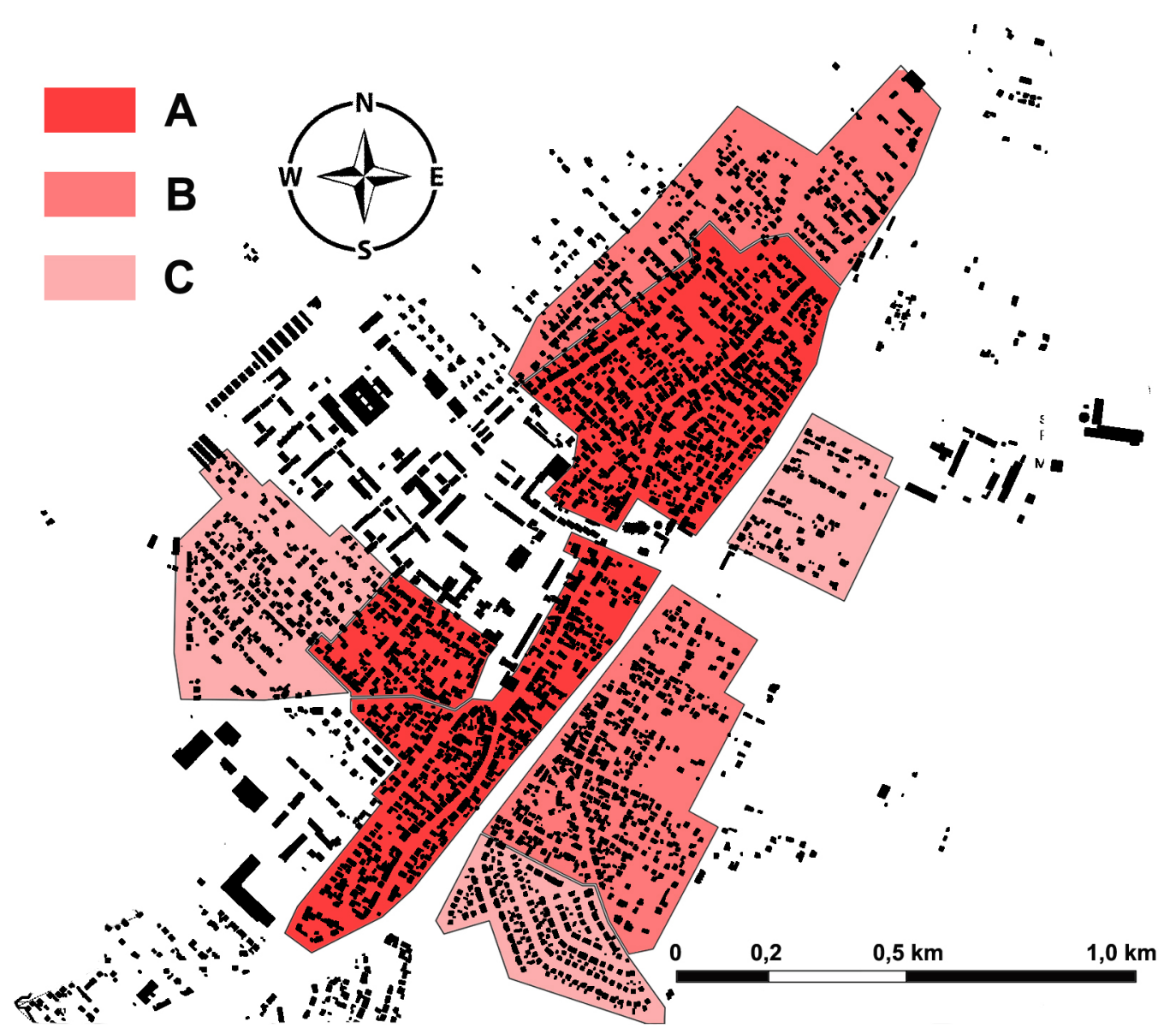

Figure 8. Three zones (A, B and C) with different morphological and environmental conditions in the city of Radzionkow, for which different spatial policies should be pursued in terms of protecting the quality of the living environment.

\section{Results and Discussion}

Radzionkow's urbanized area cannot be treated as a morphologically homogeneous structure. From the presented cross-sections of the terrain (Figure 1,2,3,4,5) it can be clearly seen that the entire urbanized area of Radzionkow is located in a small river valley located in the Szarlejka catchment, and the decrease from the North-East to South-West is $1 \%$. As illustrative and explanatory material, 4 cross-sections of the terrain profile (Figure 1,2,3,4) and one longitudinal section (Figure 5) showing the valley character of the layout of the buildings were presented. In addition, historical layers of urban tissue development indicate the development of buildings from the lowest parts to the highest areas. In order to examine specific environmental zones, 6 areas were initially adopted, in which they were selected due to their location, similar building structure in terms of age and type of facilities, and similar topography. In these areas, 60 buildings were randomly selected and analyzed and their heating and insulation method was checked. In total, 360 buildings in 6 groups of 60 buildings were tested in the city. The obtained results allowed defining and determining 3 basic urban zones characteristic in terms of heating and insulation of buildings (Figure 8). Considering the most important environmental conditions from the point of view of urban tissue ventilation, westerly and south-westerly winds encounter a natural barrier in the form of a 35-meter high hill on the eastern side of the city (Figure $1,2,3,4$ and 6). An additional obstacle is buildings placed parallel to the roads running from north-west to south-east (Figure 7). In the entire spatial arrangement of the city, only 19\% of roads are from the southwest to the northeast, the remaining $81 \%$ are roads that are mostly perpendicular, and thus not intended to ventilate the city (Figure 7). The road system mostly consists in separating them in their 
original shape after mid-field divisions running perpendicular to the slopes of hills. Considering the topographic shape of the city and the prevailing winds from the southwest - the city is very unfavourably situated and laid out in terms of the possibility of natural ventilation of the tern.

Against the background of existing building tissue, taking into account the age of the buildings, three zones A, B and C can be clearly characterized by different environmental conditions (Figure 8) allowing conclusions on necessary actions related to high dustiness. PM2.5 and PM10 occurring in the city (Figure 10).

Zone A $53 \%$ of buildings are heated with coal, zone B 39\% of buildings heated with coal, zone C $35 \%$ of buildings heated with coal, outside these zones new housing estates are heated with gas and renewable energy sources, while public buildings are heated from the network heating. In zone A, $44 \%$ of insulated buildings, in zone B, $48 \%$ of buildings are insulated, in zone C $68 \%$ of buildings are insulated, except for the designated zones, buildings constructed today are all insulated or meet the standard (Figure 8)[58].

\subsection{Characteristics of Zone A}

Zone A (Figure 8) has the worst environmental conditions since $53 \%$ of buildings are coal-fired, it is also the lowest zone in the valley at the level of $296 \mathrm{~m}$ above sea level to $306 \mathrm{~m}$ above sea level, with an average $1 \%$ slope in the opposite direction to the natural ventilation direction. This zone is limited from the south-east and north-west side by 35 hills. In this zone, only 6 streets are close to the prevailing natural winds dominating in this area, the remaining roads, i.e. approx. 39, are set perpendicular to the dominant wind direction. The ventilation of this zone is definitely the worst because it has the most cubature barriers - most of the objects located are parallel to the roads. In zone A, $44 \%$ of insulated buildings, the average is overstated by the smallest residential buildings, the largest percentage being insulated, however, emitting much less pollution than large multi-family tenements usually heated by several stage installations or central coal installations.

It is also the oldest and the most intensively built-up zone. The building intensity (floor index space) of this zone is from 0.3 - 2.0. In order to improve the quality of the environment, it is necessary to increase expenditure primarily on heating buildings in zone A by introducing subsidies in zone A for gas heating or using the existing potential in the form of the possibility of connecting to a heating system that is connected to the Jerzy Zietek housing estate. The largest stone buildings, often under conservation protection, require special expenditures.

\subsection{Characteristics of Zone $B$}

In zone B (Figure 8), 48\% of buildings are insulated, the average is inflated by buildings erected as filling construction gaps after 1980. The closer to the historic layout of the centre, the more buildings are insulated and coal-fired. On the other hand, insulated objects do not meet the requirements of WT (Technical Conditions for Buildings) of 2014, specifying the maximum energy intensity parameter at $120 \mathrm{kWh} /$ (m2year), and what traditional brick wall technology translates into insulation thickness with polystyrene or mineral wool with a lambda factor of $0.031 \mathrm{~W} /(\mathrm{mK})$ about $15 \mathrm{~cm}$ thick (Figure 9)[58]. Typically, the insulation thickness of objects ranges between 5 and $10 \mathrm{~cm}$. In zone B, 39\% of buildings are heated with coal, which significantly affects the deterioration of the quality of the environment in this area, but at the same time affects the deterioration of the environment in zone A below the valley. In area A on slopes of hills, streets perpendicular to the direction of ventilation cities is becoming natural channels of pollution towards the bottom of the valley. According to the City Hall, the average age of coal boilers in the Radzionkow area are boilers from 2003 - it can be assumed that the average age of the boiler in this area coincides with official data. Most of the buildings in this zone come from the post-war period, and they were built mostly in 1945 and 1990. 


\subsection{Characteristics of Zone $C$}

In zone C (Figure 8) $68 \%$ of insulated buildings, usually they are mostly relatively new buildings built on the outskirts of the city, the closer to the centre the number of insulated buildings decreases with their age. Most of the insulated objects are objects that do not meet the requirements of WT (Technical Conditions to be met by Buildings) from 2014 determining the maximum energy consumption parameter at the level of $120 \mathrm{kWh} /$ (m2year), in a similar way as it was in zone B [58]. Thickness of insulation of objects hesitates between 5 and $10 \mathrm{~cm}$ (Figure 9). In zone C, 35\% of buildings are heated with coal, which significantly affects the deterioration of the quality of the environment in this area, but at the same time affects the deterioration of the environment in zone A located at the bottom of the valley. According to the Municipal Office, the average age of coal boilers in the Radzionkow area is boilers 2003 - it can be assumed that the average age of the boiler in this area is slightly younger than provided by statistical data. Most of the buildings in this zone come from the post-war period and were erected in 1960 and 2010.

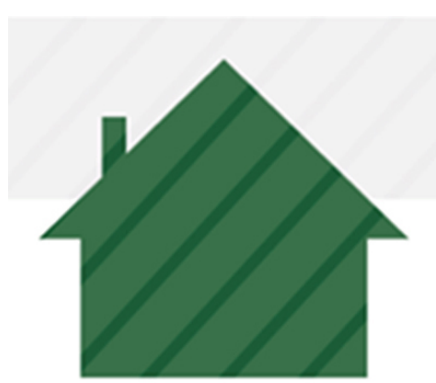

$120 \mathrm{kWh} /(\mathrm{m} 2$ year $)$ WT 2014

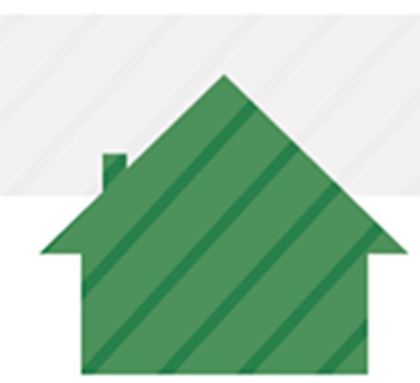

$95 \mathrm{kWh} /(\mathrm{m} 2$ year $)$ WT 2017

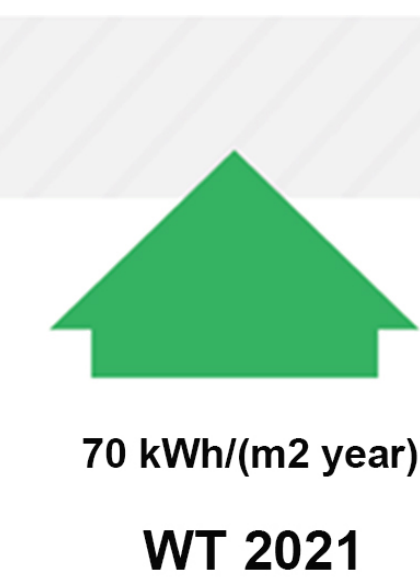

Figure 9. Change of standards related to thermomodernization in Polish legislation in accordance with the Technical Conditions to be met by buildings (WT) in $2014-120 \mathrm{kWh} / \mathrm{m} 2$ year), after 2017 maximum 95kWh/m2year, after 2021 maximum 70kWh/m2year.[58]

\subsection{Measurements of air pollution in the urban area of Radzionkow}

Currently, there is only one measuring point (Figure 10), air quality in Radzionkow located on Szymaly street outside the designated zones due to the open flattened space causing the ventilation of the location of the measurement site, at a distance exceeding $1 \mathrm{~km}$ to the west, there is no building that would be coal-fired. The measuring point is actually located on the edge of the urban area of Radzionkow in the most favourable climate. The installed measuring indicators are located at a height of approx. $6.5 \mathrm{~m}$. It should, therefore, be assumed that this indicator shows the most favourable situation in the city actually located outside the designated reliable location (A, B, C). Considering the fact that on a sunny windy day, e.g. 30/12/2019, the sensor indicators showed a PM10 dust level of $52 \mu \mathrm{g} / \mathrm{m} 3$ - acceptable daily total indicator up to $50 \mu \mathrm{g} / \mathrm{m} 3$ daily, this indicator did not fall below 50 $\mu \mathrm{g} / \mathrm{m} 3$ and at times it reached $110 \mu \mathrm{g} / \mathrm{m} 3 \mathrm{o}$, the average hourly result is approx. $65 \mu \mathrm{g} / \mathrm{m3}$, compared to the number of hours daily there is pollution in the form of PM10 suspended dust in the size of 1440 $\mu \mathrm{g} / \mathrm{m} 3$. This indicates that the indicator is exceeded by $2280 \%$ - daily, and the average daily exceeding is $130 \%$, and in total it is exceeding $360 \mu \mathrm{g} / \mathrm{m} 3$ per day - in very favourable weather conditions and in a convenient location. According to WHO recommendations, the permissible daily concentration should not be exceeded for more than 35 days a year, and the alarm level is $300 \mu \mathrm{g} / \mathrm{m3}$ (daily average).

Exceeding admissible PM 2.5 standards. In EU countries, its maximum level is $25 \mu \mathrm{g} / \mathrm{m} 3$ [? ]. In the study, at the same time at the measuring point, it was $30 \mu \mathrm{g} / \mathrm{m} 3$, while in zone A measured with a hand-held apparatus for measuring pollution it was $120 \mu \mathrm{g} / \mathrm{m} 3$, and in the rooms of an insulated 
and gas-heated building, it was $91 \mu \mathrm{g} / \mathrm{m} 3$. It follows that in zone A the test results are four times worse than those measured at the measuring point. At the same time, it proves that the standard was exceeded by $480 \%$. Daily tests performed during the highest concentration of PM2.5 at the measuring point in the amount of $75 \mu \mathrm{g} / \mathrm{m} 3$ indicated on the hand-held apparatus in zone A pollution at the level of $300 \mu \mathrm{g} / \mathrm{m} 3$, showing exceeding the standard by $1200 \%$. On less windy days in zone A - observations with the help of a hand-held measuring device exceeded $2000 \%$.

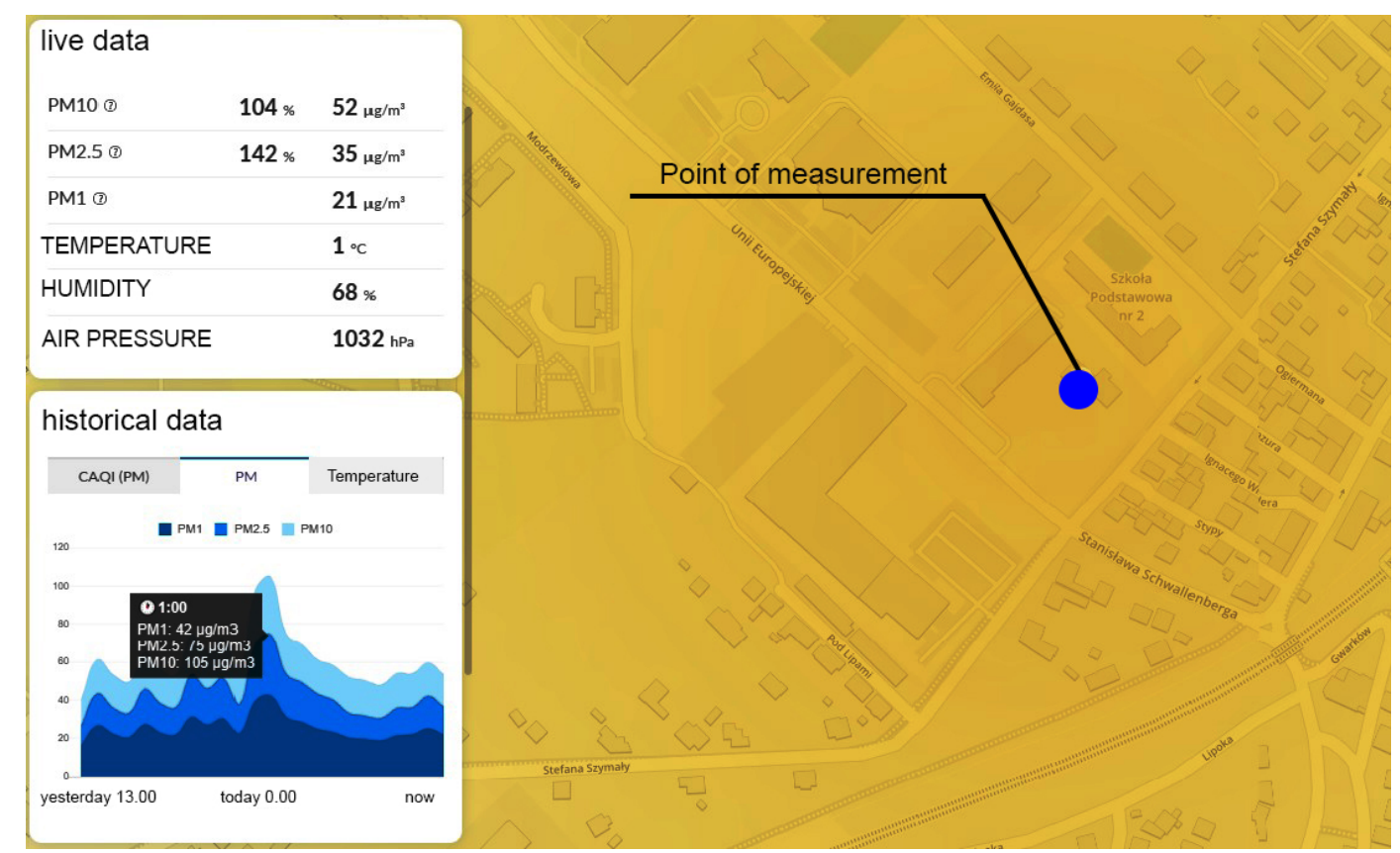

Figure 10. Air pollution at the measuring point at Szymaly street. (https://airly.eu/map).

According to official documents, in order to determine the environmental quality policy, surveys were conducted for 991 buildings / residential premises (780 detached buildings, 116 semi-detached houses, 76 terraced houses and 19 apartments in the block or tenement house), 24 enterprises and 14 public buildings. In housing, the average house / flat is $129.7 \mathrm{~m} 2$ [56], [57]. The oldest residential building dates from 1860, the newest from 2014, and the average construction date is 1961. Some people have modern boilers (the latest was from 2015), but a large group of people use outdated heating installations (the oldest from 1960). The average year of boiler production is 2003, and the average power - $20.3 \mathrm{~kW}$. On average, 4 people live in one household. For enterprises, the average heated area is $247.9 \mathrm{~m} 2$, and the average year of construction of the building is 1951 (oldest: 1800, newest: 2011). On the other hand, for used boilers, the average power is $27.5 \mathrm{~kW}$, and the year of production - 2005. For public buildings covered by the survey, the average heated area is $579.0 \mathrm{~m} 2$, and the year of construction 1960 (oldest: 1885, newest: 1986). The average boiler power is $5 \mathrm{~kW}$ (most public buildings have a connection to the heating plant and the boilers are only an additional source of heat, and those that are heated only with the help of the boiler did not know its power), and the average year of production is 2003. The commune authorities plan to replace the installation and co-financing to replace boilers for RES heating media, however, the slowness of changes did not affect the radical improvement of the environment in Radzionkow. An additional survey regarding the interest in replacing the heat source conducted on a group of 701 people showed that $81.31 \%$ are interested in replacing the heat source or purchasing renewable energy sources or a more ecological source [56],[57], but further survey showed that only $9.13 \%$ of people are interested in replacing the heating source as soon as they receive co-financing a further number of respondents in planting postpones replacement of the installation in a further - unspecified perspective. 


\section{Conclusions}

In recent years, mathematical LUR (Land Use Regression) are an alternative to conventional approaches [59]. They are used to predict the concentration of atmospheric pollution at a given location by establishing statistical relationships between pollution measurements and potential predictive variables, e.g. land use, traffic and physical features of land use [59] [60]. Occurrence of PM 2.5 and PM10 in the mostly residential zone - service does not confirm the general frequent test results that the industrial zone has higher air pollution than residential zones. This is mainly related to sources of PM2.5 and PM10 dust emissions, which in Polish realities are more closely associated with restrictive regulations and controls of zones and industrial entities. On the other hand, in the studied zones, differences in pollution are clearly noticeable with new multi-family housing and service areas. The above studies do not confirm the simulation of models [61], thus paying attention to the topographic and functional specificity of areas in Central Europe due to their historical, economic and spatial conditions.

As a result of political and economic changes that took place in the 20th century, Poland has only recently started activities aimed at promoting and supporting renewable energy. The first significant reduction of air pollutant emissions took place in Poland in the 1990s. This was due to the abandonment of old industrial technologies that caused significant environmental pollution. At that time, biomass and coal combustion technology in existing domestic boilers was quite successfully developed [62]. Unfortunately, changes in the technology and technique of individual heating of buildings in less urbanized areas occurred only to a small extent. In the municipal and multi-family housing sector in Poland, they are regulated and modernized in many places. In turn, in the private sector, low-efficiency furnaces are most often used, with no dedusting systems. The purpose of the work is to highlight the problem of reducing emissions at low altitudes with particular emphasis on topography of the area. The article contains development challenges that often face selected municipal authorities in the studied area.

The research showed that:

- the location of air pollution measurement indicators is crucial due to their readings, and well-ventilated places at altitude can significantly underestimate measurements,

- topographic altitude in the building urban areas has a very strong impact on the measurable quality of PM 2.5 and PM 10 air pollution,

- building zone shape systems preventing ventilation of the spatial structure deteriorate air quality, even in cases of quite favorable altitude location (part of zone $C$ in the southern part of Radzionkow),

- built-up basins and valleys arranged perpendicularly (corridor) to the dominant wind direction with a dominant number of streets perpendicular to the most common winds generate very unfavorable initial conditions related to the possibility of air pollution (the shape and form of the Radzionkow basin in relation to the wind rose),

- the age of construction and the type of ownership in the Silesian agglomeration determine their impact on the environment,

- residential buildings built before 1980 (zone A and B) generate the greatest air pollution,

- the smallest air pollution is generated by buildings owned by municipalities and education authorities, which are heated from the municipal heating network.

Several postulates can be specified for the case studied:

- practically for the extremely topographically bad location of the Radzionkow basin, it should be prohibited to smoke coal in zones $\mathrm{A}$ and $\mathrm{B}$, with a requirement to achieve energy consumption of buildings at the WT 2017 level, i.e. $95 \mathrm{kWh} /$ (m2year),

- in zone A, ventilation corridors should be designated first, in zone C, all buildings should be insulated 
- the co-financing planned for the insulation of buildings and supporting the replacement of boilers for gas and other heating devices using renewable energy planned in the commune should apply to zones A and B to a greater extent, the division of commune funds should take place according to the parity for the zone min; A 55\% of funds, for zone B 35\% of funds, for zone C $15 \%$ of funds, in addition, the allocated funds should include a clause on the necessity of spending them within a year of the funding received,

- the planned actions according to reducing air pollution by PM2.5 i PM10 should start from the center and move towards the outskirts of the city.

\section{References}

1. Bilgen, S.; Sarıkaya, I. Exergy for environment, ecology and sustainable development. Renew. Sustain. Energy Rev. 2015, 51, 1115-1131. [CrossRef]

2. Kampa, M.; Castanas, E. Human health efects of air pollution. Environ. Pollut. 2008, 151, 362-367. [CrossRef]

3. Hendryx, M.; Fedorko, E. The relationship between toxics release inventory discharges and mortality rates in rural and urban areas of the United States. J. Rural Health 2011, 27, 358-366. [CrossRef] [PubMed]

4. QUARG. Airborne Particulate Matter in the UK; Third Report of the Quality of Urban Air Review Group; Harrison, R.M., Ed.; Institute of Public and Environmental Health, University of Birmingham: Birmingham, UK, 1996.

5. Grewling, Ł.; Bogawski, P.; Kryza, M.; Magyar, D.; Šikoparija, B.; Skjøth, C.A.; Udvardy, O.; Wermer, M.; Smith, M. Concomitant occurrence of anthropogenic air pollutants, mineral dust and fungal spores during long-distance transport of ragweed pollen. Environ. Pollut. 2019. [CrossRef] [PubMed]

6. Kozáková, J.; Pokorná, P.; Vodicka, P.; Ondrácková, L.; Ondrácek, J.; Krumal, K.; Mikuška, P.; Hovorka, J.; Moravec, P.; Schwarz, J. The influence of local emissions and regional air pollution transport on a European air pollution hot spot. Environ. Sci. Pollut. Res. Int. 2019, 26, 1675-1692. [CrossRef] [PubMed]

7. Adamczyk, J.; Piwowar, A.; Dzikuc, M. Air protection programmes in Poland in the context of the low emission. Environ. Sci. Pollut. Res. 2017, 24, 16316-16327. [CrossRef]

8. 22. Naydenova, I.; Petrova, T.; Velichkova, R.; Simova, I. PM10 exceedance in Bulgaria. In Proceedings of the CBU International Conference Proceedings, Prague, Czech Republic, 21-23 March 2018; Volume 6, pp. 1129-1138.

9. Beloconi, A.; Chrysoulakis, N.; Lyapustin, A.; Utzinger, J.; Vounatsou, P. Bayesian geostatistical modelling of PM10 and PM2. 5 surface level concentrations in Europe using high-resolution satellite-derived products. Environ. Int. 2018, 121, 57-70. [CrossRef] [PubMed]

10. Gehrsitz, M. The efect of low emission zones on air pollution and infant health. J. Environ. Econ. Manag.2017, 83, 121-144. [CrossRef]

11. Ellison, R.B.; Greaves, S.P.; Hensher, D.A. Five years of London's low emission zone: Effects on vehicle fleet composition and air quality. Transp. Res. D Transp. Environ. 2013, 23, 25-33.[CrossRef]

12. Holman, C.; Harrison, R.; Querol, X. Review of the efficacy of low emission zones to improve urban air quality in European cities. Atmos. Environ. 2015, 111, 161-169. Energies 2019, 12, 355812 of 15.[CrossRef]

13. De Marco, A.; Proietti, C.; Anav, A.; Ciancarella, L.; D’Elia, I.; Fares, S.; Fornasier, M.F.; Fusaro, L.; Gualtieri, M.; Manes, F.; et al. Impacts of air pollution on human and ecosystem health, and implications for the National Emission Ceilings Directive: Insights from Italy. Environ. Int. 2019, 125, 320-333. [CrossRef] [PubMed]

14. Cai, B.; Liang, S.; Zhou, J.; Wang, J.; Cao, L.; Qu, S.; Xu, M.; Yang, Z. China high resolution emission database (CHRED) with point emission sources, gridded emission data, and supplementary socioeconomic data. Resour. Conserv. Recycl. 2018, 129, 232-239. [CrossRef]

15. Alyuz, U.; Alp, K. Emission inventory of primary air pollutants in 2010 from industrial processes in Turkey. Sci. Total Environ. 2014, 488, 369-381. [CrossRef]

16. Han, L.; Zhou, W.; Li, W.; Li, L. Impact of urbanization level on urban air quality: A case of fine particles (PM2.5) in Chinese cities. Environ. Pollut. 2014, 194, 163-170. [CrossRef] [PubMed] 
17. Makkonen, U.; Hellén, H.; Anttila, P.; Ferm, M. Size distribution and chemical composition of airborne particles in south-eastern Finland during different seasons and wildfire episodes in 2006. Sci. Total Environ. 2010, 408, 644-651. [CrossRef] [PubMed]

18. Pope, C.A., III; Dockery, D.W. Health effects of fine particulate air pollution: Lines that connect. J. Air Waste Manag. 2006, 56, 709-742. [CrossRef]

19. Pope, C.A.; Turner, M.C.; Burnett, R.; Jerrett, M.; Gapstur, S.M.; Diver, W.R.; Krewski, D.; Brook, R.D. Relationships between fine particulate air pollution, cardiometabolic disorders, and cardiovascular mortality. Circ. Res. 2015, 116, 108-115. [CrossRef] [PubMed]

20. Behera, S.N.; Sharma, M. Reconstructing primary and secondary components of PM2.5 composition for an urban atmosphere. Aerosol Sci. Technol. 2010, 44, 983-992. [CrossRef]

21. Wang, Z.; Hu, M.; Wu, Z.; Yue, D.; He, L.; Huang, X.; Liu, X.; Wiedensohler, A. Long-term measurements of particle number size distributions and the relationships with air mass history and source apportionment in the summer of Beijing. Atmos. Chem. Phys. 2013, 13, 10159-10170. [CrossRef]

22. Wu, D.W.; Fung, J.C.; Yao, T.; Lau, A.K. A study of control policy in the Pearl River Delta region by using the particulate matter source apportionment method. Atmos. Environ. 2013, 76, 147-161. [CrossRef]

23. Wang, Y.; Li, L.; Chen, C.; Huang, C.; Huang, H.; Feng, J.; Wang, S.; Wang, H.; Zhang, G.; Zhou, M.; et al. Source apportionment of fine particulate matter during autumn haze episodes in Shanghai, China. J. Geophys. Res. 2014, 119, 1903-1914. [CrossRef]

24. Brook, R.D.; Rajagopalan, S.; Pope, C.A.; Brook, J.R.; Bhatnagar, A.; Diez-Roux, A.V.; Holguin, F.; Hong, Y.; Luepker, R.V.; Mittleman, M.A. Particulate matter air pollution and cardiovascular disease an update to the scientific statement from the American Heart Association. Circulation 2010, 121, 2331-2378. [CrossRef] [PubMed]

25. Bell, M.L. Assessment of the Health Impacts of Particulate Matter Characteristics; Research Report, No 161; Health Effects Institute: Boston, MA, USA, 2012; pp. 5-38.

26. Fann, N.; Lamson, A.D.; Anenberg, S.C.; Wesson, K.; Risley, D.; Hubbell, B.J. Estimating the national public health burden associated with exposure to ambient PM2.5 and ozone. Risk Anal. 2012, 32, 81-95. [CrossRef] [PubMed]

27. Kim, S.Y.; Peel, J.L.; Hannigan, M.P.; Dutton, S.J.; Sheppard, L.; Clark, M.L.; Vedal, S. The temporal lag structure of short-term associations of fine particulate matter chemical constituents and cardiovascular and respiratory hospitalizations. Environ. Health Perspect. 2012, 120, 1094. [CrossRef] [PubMed]

28. Beckerman, B.S.; Jerrett, M.; Serre, M.; Martin, R.V.; Lee, S.-J.; van Donkelaar, A.; Ross, Z.; Su, J.; Burnett, R.T. A hybrid approach to estimating national scale spatiotemporal variability of PM2.5 in the contiguous. United States. Environ. Sci. Technol. 2013, 47, 7233-7241. [PubMed]

29. Geng, G.; Zhang, Q.; Martin, R.V.; van Donkelaar, A.; Huo, H.; Che, H.; Lin, J.; He, K. Estimating long-term PM2.5 concentrations in China using satellite-based aerosol optical depth and a chemical transport model.Remote Sens. Environ. 2015, 166, 262-270. [CrossRef]

30. Just, A.C.; Wright, R.O.; Schwartz, J.; Coull, B.A.; Baccarelli, A.A.; Tellez-Rojo, M.M.; Moody, E.; Wang, Y.; Lyapustin, A.; Kloog, I. Using high-resolution satellite aerosol optical depth to estimate daily PM2.5 geographical distribution in Mexico City. Environ. Sci. Technol. 2015, 49, 8576-8584. [CrossRef] [PubMed]

31. Zhang, T.; Gong, W.; Wang, W.; Ji, Y.; Zhu, Z.; Huang, Y. Ground level PM2.5 estimates over China using satellite-based geographically weighted regression (GWR) models are improved by including NO2 and enhanced vegetation index (EVI). Int. J. Environ. Res. Public Health 2016, 13, 1215. [CrossRef] [PubMed]

32. Arain, M.A.; Blair, R.; Finkelstein, N.; Brook, J.R.; Sahsuvaroglu, T.; Beckerman, B.; Zhang, L.; Jerrett, M. The use of wind fields in a land use regression model to predict air pollution concentrations for health exposure studies. Atmos. Environ. 2007, 41, 3453-3464. [CrossRef]

33. Madsen, C.; Carlsen, K.C.L.; Hoek, G.; Oftedal, B.; Nafstad, P.; Meliefste, K.; Jacobsen, R.; Nystad, W.; Carlsen, K.-H.; Brunekreef, B. Modeling the intra-urban variability of outdoor traffic pollution in Oslo,Norway-A GA 2 LEN project. Atmos. Environ. 2007, 41, 7500-7511. [CrossRef]

34. Wilton, D.; Szpiro, A.; Gould, T.; Larson, T. Improving spatial concentration estimates for nitrogen oxidesusing a hybrid me teorological dispersion/land use regression model in Los Angeles, CA and Seattle, WA.Sci. Total Environ. 2010, 408, 1120-1130. [CrossRef] [PubMed] 
35. Li, X.; Liu, W.; Chen, Z.; Zeng, G.; Hu, C.; León, T.; Liang, J.; Huang, G.; Gao, Z.; Li, Z.; et al. The application of semicircular-buffer-based land use regression models incorporating wind direction in predicting quarterly NO2 and PM10 concentrations. Atmos. Environ. 2015, 103, 18-24. [CrossRef]

36. Lam, T.; Niemeier, D. An exploratory study of the impact of common land-use policies on air quality.Transp. Res. D-Transp. Environ. 2005, 10, 365-383. [CrossRef]

37. Bandeira, J.M.; Coelho, M.C.; Sá, M.E.; Tavares, R.; Borrego, C. Impact of land use on urban mobility patterns, emissions and air quality in a Portuguese medium-sized city. Sci. Total Environ. 2011, 409, 1154-1163. [CrossRef] [PubMed]

38. Zhang, R.S.; Pu, L.J.; Liu, Z. Advances in research on atmospheric environment effects of land use and land cover change. Area Res. Dev. 2013, 32, 123-128.

39. Chen, L.D.; Sun, R.H.; Liu, H.L. Eco-environmental effects of urban landscape pattern changes: Progresses, problems and perspectives. Acta Ecol. Sin. 2013, 33, 1042-1050. [CrossRef]

40. Briggs, D.J.; de Hoogh, C.; Gulliver, J.; Wills, J.; Elliott, P.; Kingham, S.; Smallbone, K. A regression-based method for mapping traffic-related air pollution: Application and testing in four contrasting urban environments. Sci. Total Environ. 2000, 253, 151-167. [CrossRef]

41. Jerrett, M.; Arain, A.; Kanaroglou, P.; Beckerman, B.; Potoglou, D.; Sahsuvaroglu, T.; Morrison, J.; Giovis, C. A review and evaluation of intra-urban air pollution exposure models. J. Expo. Sci. Environ. Epidemiol. 2005,15, 185-204. [CrossRef] [PubMed]

42. Liu, C.; Henderson, B.H.; Wang, D.; Yang, X.; Peng, Z.-R. A land use regression application into assessing spatial variation of intra-urban fine particulate matter (PM2.5) and nitrogen dioxide (NO2) concentrations in City of Shanghai, China. Sci. Total Environ. 2016, 565, 607-615. [CrossRef] [PubMed]

43. Sun, L.; Wei, J.; Duan, D.H.; Guo, Y.M.; Yang, D.X.; Jia, C.; Mi, X.T. Impact of Land-Use and Land-Cover Change on urban air quality in representative cities of China. J. Atmos. Sol.-Terr. Phys. 2016, 142, 43-54. [CrossRef]

44. Henderson, S.B.; Beckerman, B.; Jerrett, M.; Brauer, M. Application of land use regression to estimate long-term concentrations of traffic-related nitrogen oxides and fine particulate matter. Environ. Sci. Technol.2007, 41, 2422-2428. [CrossRef] [PubMed]

45. Liu, W.; Li, X.; Chen, Z.; Zeng, G.; León, T.; Liang, J.; Huang, G.; Gao, Z.; Jiao, S.; He, X.; et al. Land use regression models coupled with meteorology to model spatial and temporal variability of NO2, and PM10, in Changsha, China. Atmos. Environ. 2015, 116, 272-280. [CrossRef]

46. Olszowski, T.; Tomaszewska, B.; Góralna-Włodarczyk, K. Air quality in non-industrialised area in the typical Polish countryside based on measurements of selected pollutants in immission and deposition phase. Atmos.Environ. 2012, 50, 139-147. [CrossRef]

47. Błaszczyk, E.; Rogula-Kozłowska, W.; Klejnowski, K.; Kubiesa, P.; Fulara, I.; Mielzyn ska-Švach, D. Indoor air quality in urban and rural kindergartens: Short-term studies in Silesia, Poland. Air Qual. Atmos. Health 2017, 10, 1207-1220. [CrossRef]

48. Kobza, J.; Geremek, M.; Dul, L. Characteristics of air quality and sources affecting high levels of PM 10 and PM 2.5 in Poland, Upper Silesia urban area. Environ. Monit. Assess. 2018, 190, 515. [CrossRef] [PubMed]

49. Zajusz-Zubek, E.; Mainka, A.; Korban, Z.; Pastuszka, J.S. Evaluation of highly mobile fraction of trace elements in PM10 collected in Upper Silesia (Poland): Preliminary results. Atmos. Pollut. Res. 2015, 6, 961-968. [CrossRef]

50. Dzikuc, M.; Kułyk, P.; Urban, S.; Dzikuc, M.; Piwowar, A. Outline of ecological and economic problems associated with the low emission reductions in the Lubuskie Voivodeship. Pol. J. Environ. Stud. 2019, 28, 65-72. [CrossRef]

51. Nguyen, T.; Park, D.; Lee, Y.; Lee, Y.C. Particulate matter (PM10 and PM2.5) in subway systems: Health-based economic assessment. Sustainability 2017, 9, 2135. [CrossRef]

52. Dabass, A.; Talbott, E.O.; Venkat, A.; Rager, J.; Marsh, G.M.; Sharma, R.K.; Holguin, F. Association of exposure to particulate matter (PM2.5) air pollution and biomarkers of cardiovascular disease risk in adult NHANES participants (2001-2008). Int. J. Hyg. Environ. Health 2016, 219, 301-310. [CrossRef]

53. Błaszczyk, E.; Rogula-Kozłowska,W.; Klejnowski, K.; Fulara, I.; Mielzy nska-Švach, D. Polycyclic aromatic hydrocarbons bound to outdoor and indoor airborne particles (PM2.5) and their mutagenicity and carcinogenicity in Silesian kindergartens, Poland. Air Qual. Atmos. Health 2017, 10, 389-400. 
54. Kujda, Ł.; Kozacki, D.; Pociech, D.; Hryniewicz, M. Effect of the renewable energy resources on the reduction of pollution emissions from the rural areas. Probl. Agric. Eng. 2016, 93, 59-67.

55. Directive 2008/50 / EC of the European Parliament and of the Council of 21 May 2008 on ambient air quality 192 and cleaner air for Europe. https: / / eur-lex.europa.eu/legal-content/en/ALL/?uri = Celex

56. Low-emission economy plan for the Radzionkow commune for the years 2015-2020. Update of the draft assumptions to the plan for the supply of heat, electricity and gas fuels for the Radzionkow commune, July 2018, http:/ / www.bip.radzionkow.pl/?p=documentaction=showid=27696bar_id=17663

57. Municipal subsidies for boiler replacement in Radzionkow. http://www.radzionkow.pl/ochrona-zasobow-srodowiska/powietr

58. Regulation of the Minister of Infrastructure of 12 April 2002 on the technical conditions to which buildings and their location should correspond. http:/ / prawo.sejm.gov.pl/isap.nsf/DocDetails.xsp?id=WDU20020750690

59. Olvera, H.A.; Garcia, M.; Li, W.-W.; Yang, H.; Amaya, M.A.; Myers., O.; Burchiel, S.W.; Berwick, M.; Pingitore, N.E., Jr. Principal component analysis optimization of a PM2.5 land use regression model with small monitoring network. Sci. Total Environ. 2012, 425, 27-34. [CrossRef] [PubMed]

60. Briggs, D.J.; Collins, S.; Elliott, P.; Fischer, P.; Kingham, S.; Lebret, E.; Pryl, K.; Reeuwijk, H.V.; Smallbone, K.; Van Der Veen, A. Mapping urban air pollution using GIS: A regression-based approach. Int. J. Geogr. Inf. Sci. 1997, 11, 699-718. [CrossRef]

61. He, Z.J.; Yuan, S.L.; Xiao, M. Pollution levels of airborne particulate matter PM10 and PM2.5 in summer inNanchang City. J. Anhui Agric. Sci. 2009, 38, 1336-1338.

62. Dzikuc, M.; Piwowar, A. Ecological and economic aspects of electric energy production using the biomass co-firing method. The case of Poland. Renew. Sustain. Energy Rev. 2016, 55, 856-862. [CrossRef]

Sample Availability: Samples of the compounds ...... are available from the authors. 